\title{
LIBRARIES UNLIMITED
}

-Just Released-

\section{INDEPENDENT UKRAINE}

\section{A Bibliographic Guide to English-Language Publications, 1989-1999}



Review of the previous edition:

"The bibliography is in a real sense an intelligent guide to Ukrainian studies. The structuring of the work is a model for other bibliographers."

Slavic Review

\section{Also Available}

- Ukraine: A Bibliographic

Guide to English-Language

\section{Publications}

Bohdan S. Wynar

0-87287-761-2 \$65.00 Retail

- Ukrainian Nationalism

3d Edition

John A. Armstrong

0-87287-755-8 \$45.00 Retail

\section{Bohdan S. Wynar}

Scholarly works and research regarding all things Ukrainian have increased dramatically during the nation's first decade of independence, and so too has the need for a guide to the ever-growing volume of publications. This work responds with approximately 1,700 evaluative annotations describing key books, articles, scholarly essays, and doctoral dissertations published about Ukraine in the past decade.

This volume complements and supplements Wynar's previous work, Ukraine: $A$ Bibliographic Guide to English-Language Publications, published in 1990. Together the two books provide a standard of bibliographic control and a comprehensive overview of the intellectual activity in the field.

$$
\begin{aligned}
& 2000 \text { xiv, 552p. } 7 \times 10 \text { cloth } \\
& \text { ISBN 1-56308-670-0 \$85.00 Retail }
\end{aligned}
$$

- Modern Ukrainian Short Stories Revised First Edition Edited by George S. N. Luckyj 1-56308-391-4 \$27.50 Retail

- A History of Ukrainian Literature: From the 11th to the End of the 19th Century, 2d Edition

Dmytro Cyzevs'kyi 1-56308-522-4\$75.00 Retail 


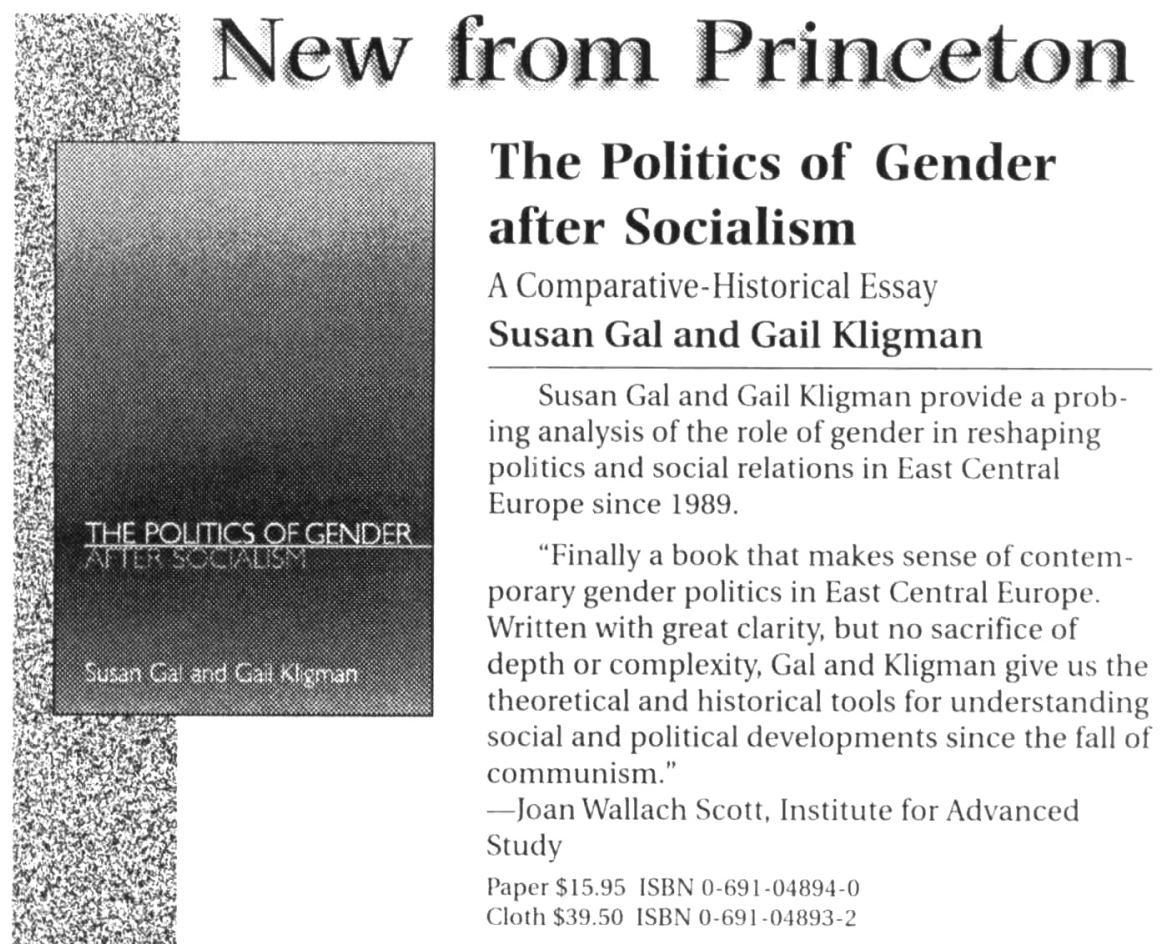

\section{Reproducing Gender}

Politics, Publics, and Everyday Life after

Socialism

\section{Edited by Susan Gal and Gail Kligman}

This book presents detailed evidence about women's and men's new circumstances in eight of the former communist countries, exploring the intersection of politics and the life cycle, the differential effects of economic restructuring, and women's public and political participation.

"This is an excellent and timely collection of essays, which I highly recommend. [The] essays are based on serious primary research that combines the regional traditions of scholarship with disciplined social science methods and style." -Eva Fodor, Dartmouth College

Paper \$24.95 ISBN 0-691-04868-1

Cloth \$65.00S ISBN 0-691-04867-3 Due May

\section{Princeton University Press}

AT FINE BOOKSTORES OR CALL 800-777-4726 - WWW.PUP.PRINCETON.EDU 




\section{In the Shadow of Revolution}

Life Stories of Russian Women from 1917 to the Second World War Edited by Sheila Fitzpatrick
and Yuri Slezkine

A collection of life stories of Russian women in the first half of the twentieth century, In the Shadow of Revolution brings together the testimony of Soviet citizens and émigrés, intellectuals and milkmaids, housewives and engineers. This is an accessible anthology that reveals both the diversity and similarity of the experiences of Russian women.

"A pleasure to read and hugely absorbing. The variations in the memoirs ... give one of the best introductions possible to Soviet history."-Elizabeth A. Wood, MIT

Paper \$24.95 ISBN 0-691-01949-5

Cloth $\$ 65.00$ ISBN 0-691-01948-7 Due June

\section{New in paperback The Coasts of Bohemia}

A Czech History

\section{Derek Sayer}

"An ambitious, elegantly written, and sympathetic account of the art, the literature and the politics of the Czech people.... Sayer saunters gracefully and with sure footing back and forth across centuries of Czech religion, mythology, and history, displaying enthusiasm and engagement. ... His book is a delight."-Tony Judt, The New Republic

"A rich and intricate story. ... Excellent ... the most stimulating introduction to [its] subject available in English, or ... any other language."-R. J. W. Evans, New York Review of Books

Paper \$18.95 ISBN 0-691-05052-X 


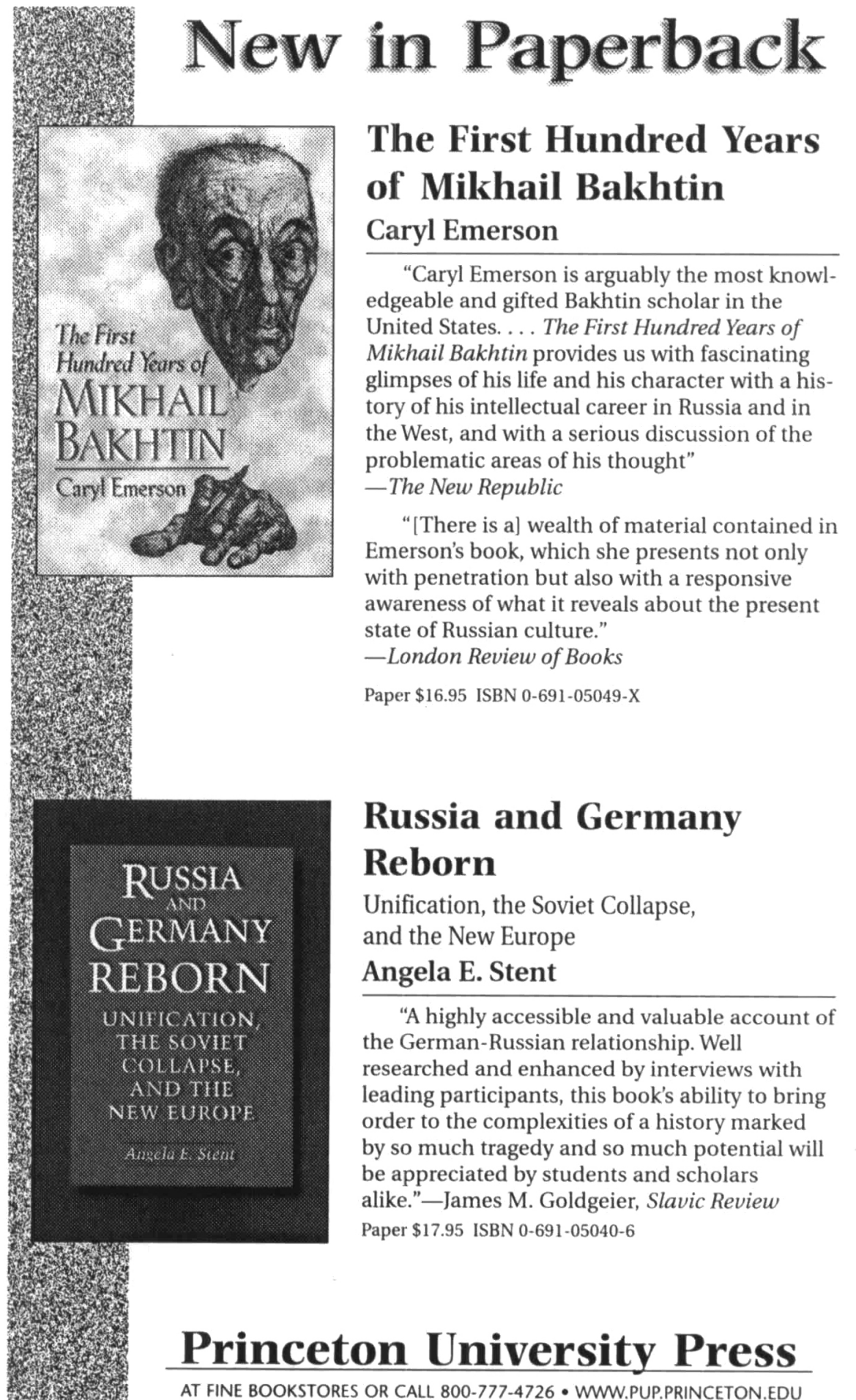

AT FINE BOOKSTORES OR CALL 800-777-4726 - WWW.PUP.PRINCETON.EDU 


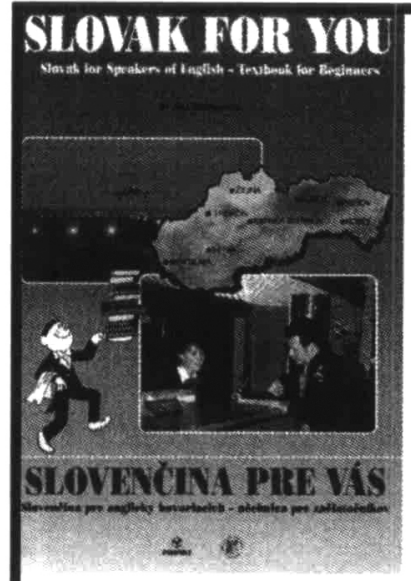

\section{Slovak for You: \\ Slovak for Speakers of English \\ A Beginning Textbook \\ by Dr. Ada Böhmerová}

An excellent beginning language text, Slovak for You is designed for classroom use with students ranging from secondary level to adult learners. It covers the sounds of the Slovak alphabet and the basics of daily conversation for social situations and travel.

The supplementary audiocassettes provide "listen and repeat" drills from Chapters 1-4 of the text, including 4 folk songs.

Book: $81 / 4$ x 11 1/2, 144 pp., 145 color photos, 50 color illus., 4 color maps, 14 songs with music (1996), Paperback, ISBN 0-86516-331-6, \$30.00

Set of 2 Cassettes: (1999) 2 Audio cassettes, ISBN 0-86516-469-X, $\$ 30.00$

\section{Bolchazy-Carducci Publishers, Inc.}

1000 Brown St., \#101, Wauconda, IL 60050

Phone: (847) 526-4344; Fax: (847) 526-2867

E-mail: orders@bolchazy.com; Website: http://www.bolchazy.com

\section{New from Columbia.}

\section{Russia and the Idea of the West \\ Gorbachev, Intellectuals, and \\ the End of the Cold War}

\section{Robert D. English}

"An excellent in-depth analysis of the intellectual origins of the 'new thinking'-how it came to power and changed the world." -Thomas Risse, European Univ. Institute 256 pages $\bullet \$ 18.50$ paper

\section{Religion and the Politics of} Identity in Kosovo Gerlachus Duijzings

A new perspective on the ambiguities of identities shaped by conditions of violence and insecurity.

250 pages $\bullet \$ 27.50$ cloth

\section{Islam and the Soviet Union} From the Second World War to Gorbachev Yaacov Ro'i

How and why did Islam survive in the Soviet Union? In the most detailed historical study of Islam under post-war Soviet communism yet published-and the first based largely on official Soviet archival material-Ro'i surveys the Muslim faith's situation in the Soviet domestic scene.

600 pages $\cdot \$ 55.00$ cloth

\section{Explaining Yugoslavia John B. Allcock}

A look at Balkan history in the context of other societies' development and global modernization. 400 pages $\bullet \$ 30.00$ cloth 



U.S.-RUSSIAN RELATIONS at the Turn of the Century

Reports of the Working Groups organized by the Carnegie Endowment for International Peace, Washington, D.C., and the Council on Foreign and Defense Policy, Moscow

"Provides a valuable and unique opportunity to compare the views of leading American and Russian experts and former officials on the troubled state of U.S.-Russian relations and their prescriptions for starting to repair them."

\section{—Richard G. Lugar, United States Senator}

Includes both English and Russian language texts.

224 pp. \$9.95 paper 0-87003-177-5

GETTING IT WRONG

Regional Cooperation and the Commonwealth of Independent States Martha Brill Olcott, Anders Åslund, and Sherman W. Garnett

"The first systematic, broad-based attempt to size up the Commonwealth of Independent States. ... A unique and useful book."

-Foreign Affairs

272 pages $\$ 19.95$ paper: 0-87003-171-6
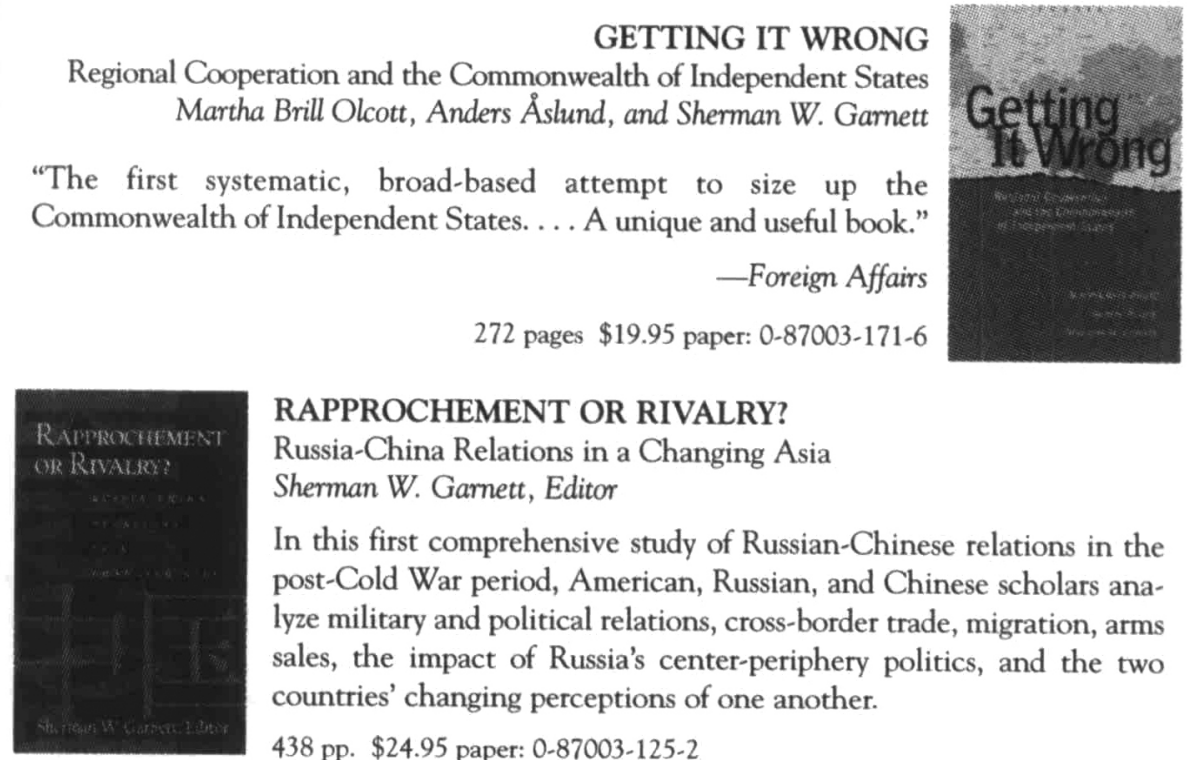

RAPPROCHEMENT OR RIVALRY?

Russia-China Relations in a Changing Asia

Sherman W. Garnett, Editor

In this first comprehensive study of Russian-Chinese relations in the post-Cold War period, American, Russian, and Chinese scholars analyze military and political relations, cross-border trade, migration, arms sales, the impact of Russia's center-periphery politics, and the two countries' changing perceptions of one another.

438 pp. $\$ 24.95$ paper: $0-87003-125-2$

\section{BELARUS AT THE CROSSROADS Sherman W. Garnett and Robert Legvold, Editors}

Area specialists from Belarus, Russia, Poland, Ukraine, Lithuania, and the United States examine Belarus's place in the evolving European security environment. No other publication has taken such a diverse approach to this little-understood country.

200 pp. $\$ 12.95$ paper: 0-87003-172-4



CARNEgIE ENDOWMENT FOR INTERNATIONAL PEACE www.ceip.org 1-800-275-1447 


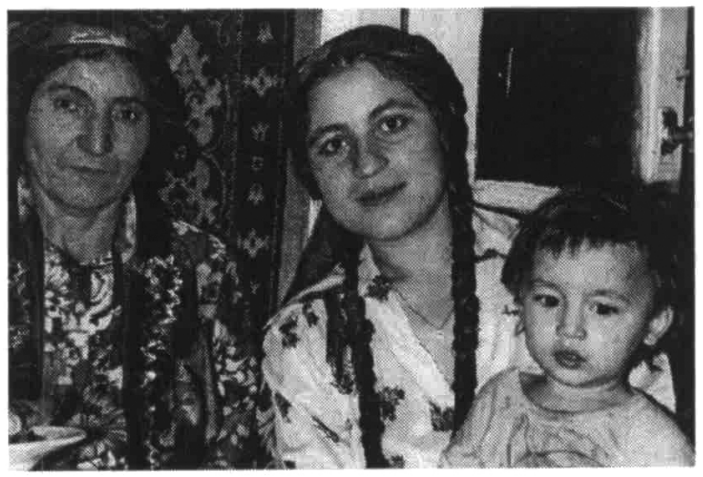

NEW FROM DUNE

\section{Between Two Fires}

\section{Gypsy Performance and Romani Memory} from Pushkin to Post-Socialism

\section{ALAINA LEMON}

Since Tsarist times, Roma in Russia (known to others as Gypsies) have been portrayed as rebels, isolated from society and excluded from mainstream history. In Soviet times, Russians harbored two opposing views of Roma, exalting Romani theater and song but believing Gypsies in the street to be liars and thieves. Alaina Lemon's ethnographic study examines how Roma themselves have negotiated such dualities, in both everyday interactions and in stage performances.

"This is an extraordinarily insightful account of the performance of being 'Gypsy' in Russia. Theoretically sophisticated, it illuminates Russian as well as Romani culture, and delves into issues of naming, mobility, transgression and authenticity. This book is a must for anyone interested in advances in anthropology as well as contemporary Russian culture." - Caroline Humphrey, co-author of The End of Nomadism?: Society, State, and the Environment in Inner Asia $27^{2}$ pages, paper $\$ 17.95$ 


\section{Forthcoming in Slavic Review}

\section{Articles}

Thomas F. Remington : The Evolution of Executive-Legislative Relations in Russia since 1993

Ronald Vroon : Aleksandr Sumarokov's Eligii liubovnye and the Development of Verse Narrative in the Eighteenth Century: Toward a History of the Russian Lyric Sequence Alyssa W. Dinega : A Russian Psyche: Sexual Transcendence in Tsvetaeva's Poems to Pasternak

Susan P. McCaffray : What Should Russia Be? Patriotism and Political Economy in the Thought of N. S. Mordvinov

Serhy Yekelchyk : "Diktat" and Dialogue in Stalinist Culture: Staging Patriotic Historical Opera in Soviet Ukraine, 1936-1954

Robert D. Greenberg : Language Politics in Yugoslavia: The Crisis over the Future of Serbian 


\section{TO THOSE WISHING TO SUBMIT MANUSCRIPTS}

Manuscripts for consideration should be printed on a letter-quality or near letter-quality printer and submitted by post or courier in four doublespaced copies. Notes and block quotations should also be double-spaced; notes should be placed at the end of the manuscript and not at the bottoms of pages. Library of Congress transliteration and the Chicago Manual of Style are to be followed. Manuscripts are sent to outside readers in anonymous form and should be prepared accordingly.

In general, articles should not exceed 8,000 words, excluding endnotes. Please indicate the word count on the cover page of the manuscript. Accepted manuscripts will be copyedited electronically, and authors will be asked to submit final versions on computer diskette. Submissions will not be returned.

The policy of Slavic Review is not to consider materials that have been published or that are being considered for publication elsewhere.

Slavic Review does not ordinarily accept unsolicited book reviews. Please consult us in advance of submitting an uninvited book review.

Slavic Review is the journal of the American Association for the Advancement of Slavic Studies, whose members support the journal through their dues. Slavic Review expects the authors of articles published in the journal to belong to the association. 